\title{
Furosemide use and survival in patients with esophageal or gastric cancer: a population-based cohort study
}

\author{
Peipei Liu', Úna C. McMenamin', Andrew D. Spence ${ }^{1,2}$, Brian T. Johnston², Helen G. Coleman ${ }^{1,3}$ and \\ Chris R. Cardwell ${ }^{1 *}$ (D)
}

\begin{abstract}
Background: Pre-clinical studies have shown that furosemide slows cancer cell growth by acting on the Na-K-2Cl transporter, particularly for gastric cancer cells. However, epidemiological studies have not investigated furosemide use and mortality in gastroesophageal cancer patients. Consequently, we conducted a population-based study to investigate whether furosemide use is associated with reduced cancer-specific mortality in esophageal/gastric cancer patients.

Methods: A cohort of patients newly diagnosed with esophageal or gastric cancer between 1998 and 2013 were identified from English cancer registries and linked to the Clinical Practice Research Datalink to provide prescription records and the Office of National Statistics to provide death data up to September 2015. Time-dependant Cox-regression models were used to calculate hazard ratios (HRs) comparing cancer-specific mortality in furosemide users with non-users. Analyses were repeated restricting to patients with common furosemide indications (heart failure, myocardial infarction, edema or hypertension) to reduce potential confounding.
\end{abstract}

Results: The cohort contained 2708 esophageal cancer patients and 2377 gastric cancer patients, amongst whom 1844 and 1467 cancer-specific deaths occurred, respectively. Furosemide use was not associated with reduced cancerspecific mortality overall (adjusted HR in esophageal cancer $=1.28,95 \% \mathrm{Cl} 1.10,1.50$ and in gastric cancer $=1.27,95 \% \mathrm{Cl}$ $1.08,1.50$ ) or when restricted to patients with furosemide indications before cancer diagnosis (adjusted HR in esophageal cancer $=1.07,95 \% \mathrm{Cl} 0.88,1.30$ and in gastric cancer $=1.18,95 \% \mathrm{Cl} 0.96,1.46)$.

Conclusions: In this large population-based cohort study, furosemide was not associated with reduced cancer-specific mortality in patients with esophageal or gastric cancer.

Keywords: Epidemiology, Pharmacoepidemiology, Furosemide, Esophageal cancer, Gastric cancer, Mortality, Survival

\section{Background}

Esophageal and gastric cancer are the seventh and fifth most commonly diagnosed cancers worldwide, accounting for around 509,000 and 783,000 deaths annually [1]. The prognosis of esophageal and gastric cancer is poor even in developed countries, for instance in the United Kingdom (UK) the 5-year survival rate for both is under

\footnotetext{
* Correspondence: c.cardwell@qub.ac.uk

${ }^{1}$ Centre for Public Health, Queen's University Belfast, Institute for Clinical Science, Royal Victoria Hospital, Grosvenor Road, Belfast, Belfast, Northern Ireland BT12 6BJ, UK

Full list of author information is available at the end of the article
}

$20 \%$ [2], highlighting the importance of investigating new treatment options.

Furosemide, a loop diuretic, is commonly prescribed for patients with pulmonary edema caused by left ventricular heart failure and chronic heart failure [3, 4], and is also used to treat resistant edema and resistant hypertension through increasing urine production [5, 6]. Furosemide acts on the thick ascending limb of the loop of Henle, where it can block the luminal $\mathrm{Na}-\mathrm{K}-2 \mathrm{Cl}$ (NKCC) transporter, a protein that transports sodium, potassium, and chloride between intracellular and extracellular fluid, thereby changing the osmotic pressure to increase the urine production $[7,8]$. NKCC are

(c) The Author(s). 2019 Open Access This article is distributed under the terms of the Creative Commons Attribution 4.0 International License (http://creativecommons.org/licenses/by/4.0/), which permits unrestricted use, distribution, and reproduction in any medium, provided you give appropriate credit to the original author(s) and the source, provide a link to the Creative Commons license, and indicate if changes were made. The Creative Commons Public Domain Dedication waiver (http://creativecommons.org/publicdomain/zero/1.0/) applies to the data made available in this article, unless otherwise stated. 
found with two subtypes, ubiquitous NKCC1 and kidney-specific NKCC2, both of which are sensitive to furosemide [9].

Recently, evidence has emerged that the NKCC plays an important role in cancer cell growth. It has been shown that overexpression of the NKCC can induce cell proliferation $[10,11]$. An in-vitro cell study found that NKCC1 expression was three times higher in poorly differentiated compared with moderately differentiated gastric adenocarcinoma cells [12]. This study also showed that furosemide reduced cell growth in poorly differentiated gastric adenocarcinoma cells, and suggested this action was via the inhibition of NKCC [12]. Consistently, NKCC1 was found to have higher expression in more poorly differentiated esophageal squamous-cell carcinoma (SCC) cases and depletion of NKCC1 inhibited cell proliferation [13]. Despite this preclinical evidence suggesting furosemide could slow gastroesophageal cancer progression, no studies have been conducted to investigate a potential association in humans.

Therefore, we conducted a large population-based cohort study to investigate whether furosemide use influences esophageal/gastric cancer-specific mortality.

\section{Methods}

\section{Data source}

Clinical Practice Research Datalink (CPRD) database is a primary care research database which covers nearly 11.3 million patients, accounting for approximately $6.9 \%$ of the UK population, and captures diagnoses, prescriptions and demographic information [14]. We obtained data from CPRD that was linked to the National Cancer Data Repository (NCDR) and the Office of National Statistics (ONS) mortality data. The NCDR contains cancer information from all English cancer registers, capturing diagnosis date, tumor characteristics and treatments. The ONS mortality data records cause and date of death.

Ethical approval for all purely observational research using CPRD data has been obtained from the East Midlands-Derby Research Ethics Service Committee (reference number: $05 / \mathrm{MRE} 04 / 87$ ). The study protocol was approved by The Independent Scientific Advisory of the Clinical Practice Research Datalink in 2015 (protocol number: 15_096RMn3).

\section{Study design and population}

A cohort of newly diagnosed esophageal and gastric cancer patients was ascertained from English cancer registries between 1998 and 2013 using International Classification of Disease (ICD) codes C15 and C16, respectively. Individuals with previous cancer (apart from non-melanoma skin cancer or in situ tumors) were excluded using a list of Read codes modified for use in the CPRD database [15]. All eligible cases were further classed as adenocarcinoma (using ICD for Oncology (ICD-O) morphology codes 8140-8573) or SCC (ICD-O 8050-8082). Deaths from esophageal or gastric cancer were identified up to September 2015 based upon the underlying cause of death (from the ONS mortality data) using ICD codes C15, C16 and C26. Therefore, participants were followed until the earliest following event occurred: 1) participants ended their registration with the general practitioner (GP); 2) last data collection from GP; 3) patients died; 4) September 2015 at which time ONS follow-up ended.

\section{Definition of exposure}

Furosemide was identified within GP prescription records based upon the British National Formulary. Overall, $78 \%$ of furosemide prescriptions were $40 \mathrm{mg}$, $20 \%$ were $20 \mathrm{mg}$. The daily defined doses (DDD) in each prescription were calculated by multiplying the quantity by the strength (in $\mathrm{mg}$ ) and dividing by the $\mathrm{mg}$ in a DDD from the World Health Organization [16].

\section{Covariates}

Lifestyle risk factors were obtained from GP records, including smoking status (never, former, current), alcohol consumption (never, former, current), and body mass index (BMI in $\mathrm{kg} / \mathrm{m}^{2}$ categorised as: underweight $<18.5$; normal weight 18.5 to 25 ; overweight: 25 to 30 and obese: $\geq 30$ ). For these lifestyle risk factors, we extracted the closest records before esophageal/gastric cancer diagnosis, and ignored records more than 10 years before the diagnosis. Comorbidities at any time before cancer diagnosis were identified from the CPRD database according to the Charlson Comorbidity Index, including AIDS, cerebrovascular disease, chronic pulmonary disease, congestive heart disease, dementia, diabetes, diabetes with complications, hemiplegia, mild liver disease, moderate liver disease, myocardial infarction (MI), peptic ulcer disease, peripheral vascular disease, renal disease and rheumatological disease [15]. Deprivation was determined from the patients' postcode based on the 2010 Index of Multiple Deprivation Score [17]. Also, furosemide indications including heart failure (HF) [18], MI [19], edema (Read code categories listed in Table 5 in Appendix) and hypertension [19] prior to cancer diagnosis were identified from the CPRD database using Read codes. Statin and aspirin use after diagnosis were also identified from GP records as previous studies have 
suggested these drugs could reduce mortality in patients with gastric or esophageal cancer [20, 21]. Patients using antihypertensive medications (diuretics, vasodilator antihypertensive drugs, centrally acting antihypertensive drugs, alpha-adrenoceptor blocking drugs, beta-blockers, angiotensin converting enzyme inhibitors, angiotensin receptor blockers, renin inhibitors and calcium channel blockers) were identified from prescription records [22].

\section{Statistical analysis}

Summary statistics and frequencies were determined for patient characteristics by furosemide use.

In the primary analyses, patients who died within 6 months were excluded as it seems unlikely that medication use after diagnosis could benefit such patients. Therefore, individuals were followed from 6 months after diagnosis to cancer-specific death or censoring. Furosemide use was treated as a time-varying covariate, to avoid immortal time bias [23]. We also utilised a lag, as recommended, to remove prescriptions in the period immediately prior to death in order to minimise potential reverse causation [24]. The study design is illustrated in Fig. 1. Individuals were regarded as furosemide nonusers until 6 months after their first prescription, at which point they were considered furosemide users until the end of follow-up. Hazard ratios (HR) and 95\% confidence intervals $(\mathrm{CI})$ were calculated using Cox regression models before and after adjustment for relevant confounders. The main model contained the following confounders: year of diagnosis, age at diagnosis, sex, deprivation, comorbidities (cerebrovascular disease, chronic pulmonary disease, congestive heart disease, diabetes, myocardial infarction, peptic ulcer disease, peripheral vascular disease, renal disease, rheumatological disease and liver disease), post-diagnosis statin or aspirin use as time-varying covariates as furosemide, and cancer treatment (surgery, radiotherapy and chemotherapy within 6 months after diagnosis). An exposure-response analysis was calculated using a time-varying covariate to
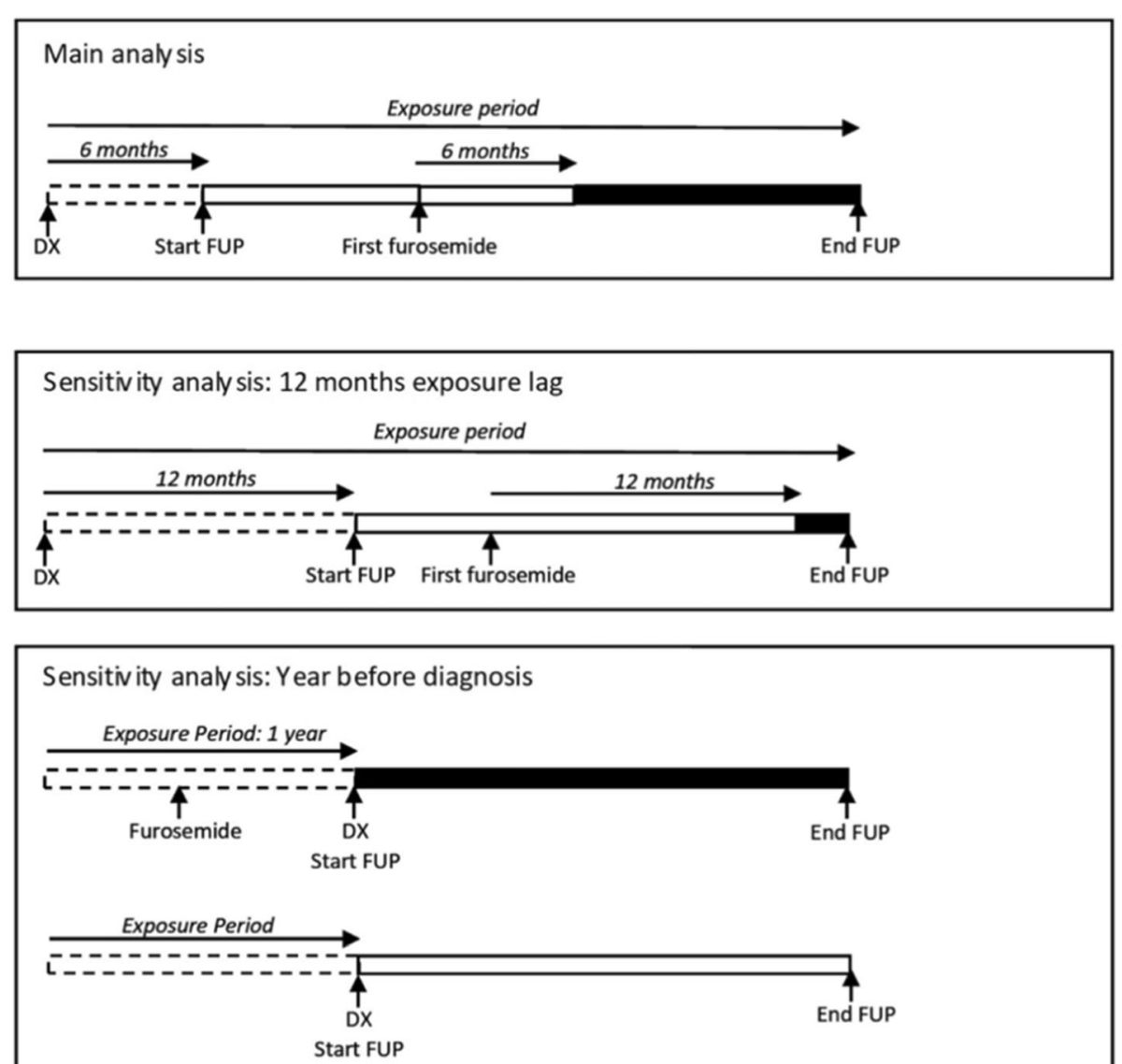

FUP: follow-up period; DX: esophageal or gastric cancer diagnosis

Legend: $\mathrm{L}_{---}^{-}$Before FUP $\square$ Furosemide user $\square$ Non-furosemide user

Fig. 1 Figure illustrating the study design in the main and sensitvity analyses of furosemide and cancer-specific mortality 
Table 1 Patients clinical characteristics by furosemide users and non-users

\begin{tabular}{|c|c|c|c|c|c|}
\hline & & & n (\%) & & \\
\hline & & Users & Never-users & Users & Never-users \\
\hline Year of diagnosis & 1998-2002 & $85(25 \%)$ & $482(20 \%)$ & $116(31 \%)$ & $507(25 \%)$ \\
\hline & 2003-2007 & $123(36 \%)$ & $789(33 \%)$ & $126(34 \%)$ & 719 (36\%) \\
\hline & 2008-2013 & 135 (39\%) & $1094(46 \%)$ & $130(35 \%)$ & 779 (39\%) \\
\hline Age at diagnosis: mean & & 74.5 & 68.2 & 76.5 & 69.6 \\
\hline & $<60$ & $25(7 \%)$ & $564(24 \%)$ & $21(6 \%)$ & $408(20 \%)$ \\
\hline & $60-69$ & $86(25 \%)$ & 755 (32\%) & $64(17 \%)$ & $506(25 \%)$ \\
\hline & $70-79$ & $124(36 \%)$ & $655(28 \%)$ & $150(40 \%)$ & $698(35 \%)$ \\
\hline & $80+$ & $108(31 \%)$ & 391 (17\%) & 137 (37\%) & $393(20 \%)$ \\
\hline Gender & Male & $217(63 \%)$ & $1611(68 \%)$ & $241(65 \%)$ & $1368(68 \%)$ \\
\hline Deprivation quintile & 1 (least deprived) & $63(18 \%)$ & $501(21 \%)$ & $68(18 \%)$ & 381 (19\%) \\
\hline & 2 & $86(25 \%)$ & $602(25 \%)$ & $93(25 \%)$ & $480(24 \%)$ \\
\hline & 3 & $70(20 \%)$ & 469 (20\%) & $61(16 \%)$ & $413(21 \%)$ \\
\hline & 4 & $71(21 \%)$ & $446(19 \%)$ & $81(22 \%)$ & $429(22 \%)$ \\
\hline & 5 (most deprived) & $53(15 \%)$ & $346(15 \%)$ & 69 (19\%) & 299 (15\%) \\
\hline Treatment & Surgery & $125(36 \%)$ & $959(41 \%)$ & $181(49 \%)$ & 1029 (51\%) \\
\hline & Chemotherapy & $116(34 \%)$ & $1178(50 \%)$ & $76(20 \%)$ & 784 (39\%) \\
\hline & Radiotherapy & $108(31 \%)$ & $591(25 \%)$ & $30(8 \%)$ & $130(6 \%)$ \\
\hline Tumor type & Adenocarcinoma & $214(62 \%)$ & 1391 (59\%) & $303(81 \%)$ & 1581 (79\%) \\
\hline & Squamous & 99 (29\%) & 716 (30\%) & $<5^{\mathrm{a}}$ & $19(1 \%)$ \\
\hline & Others & $30(9 \%)$ & $258(11 \%)$ & $64-69^{a}$ & $405(20 \%)$ \\
\hline Grade & 1 & $17(7 \%)$ & $92(5 \%)$ & $18(7 \%)$ & $69(5 \%)$ \\
\hline & 2 & $131(53 \%)$ & 775 (44\%) & $103(40 \%)$ & $484(33 \%)$ \\
\hline & 3 & $93-98^{a}$ & $892(50 \%)$ & $132-137^{a}$ & $892(61 \%)$ \\
\hline & 4 & $<5^{\mathrm{a}}$ & $16(1 \%)$ & $<5^{\mathrm{a}}$ & $17(1 \%)$ \\
\hline & Missing & 97 & 590 & 114 & 543 \\
\hline Stage & 1 & $8(17 \%)$ & $36(8 \%)$ & $7(16 \%)$ & $33(12 \%)$ \\
\hline & 2 & $10(21 \%)$ & $86(18 \%)$ & $9(21 \%)$ & $54(20 \%)$ \\
\hline & 3 & $20(43 \%)$ & $208(44 \%)$ & $8(19 \%)$ & $67(28 \%)$ \\
\hline & 4 & $9(19 \%)$ & $143(30 \%)$ & 19 (44\%) & $116(43 \%)$ \\
\hline & Missing & 296 & 1892 & 329 & 1735 \\
\hline Other medication use $\mathrm{b}^{\mathrm{b}}$ & Statin & $133(39 \%)$ & $553(23 \%)$ & $164(44 \%)$ & $479(24 \%)$ \\
\hline & Aspirin & $146(43 \%)$ & $423(18 \%)$ & $132(35 \%)$ & $366(18 \%)$ \\
\hline Smoking & Never & $101(43 \%)$ & 701 (39\%) & $103(39 \%)$ & 609 (42\%) \\
\hline & Former & $94(40 \%)$ & $621(35 \%)$ & $123(46 \%)$ & $510(35 \%)$ \\
\hline & Current & $42(18 \%)$ & $473(26 \%)$ & $39(15 \%)$ & $318(22 \%)$ \\
\hline & Missing & 106 & 570 & 107 & 568 \\
\hline Alcohol consumption & Never & $36(16 \%)$ & $235(15 \%)$ & $51(20 \%)$ & $243(18 \%)$ \\
\hline & Former & $7(3 \%)$ & $63(4 \%)$ & $12(5 \%)$ & $45(3 \%)$ \\
\hline & Current & $184(81 \%)$ & $1322(82 \%)$ & $191(75 \%)$ & $1030(78 \%)$ \\
\hline & Missing & 116 & 745 & 118 & 687 \\
\hline BMI & Underweight $(<18.5)$ & $6(3 \%)$ & $68(5 \%)$ & $<5^{\mathrm{a}}$ & $50(4 \%)$ \\
\hline & Normal (18.5-24.9) & $63(29 \%)$ & $549(38 \%)$ & $64-69^{a}$ & $429(35 \%)$ \\
\hline & Overweight (25-29.9) & 86 (39\%) & $531(37 \%)$ & 91 (39\%) & 504 (41\%) \\
\hline
\end{tabular}


Table 1 Patients clinical characteristics by furosemide users and non-users (Continued)

\begin{tabular}{|c|c|c|c|c|c|}
\hline & & \multicolumn{2}{|c|}{ Esophageal n (\%) } & \multicolumn{2}{|c|}{ Gastric n (\%) } \\
\hline & & Users & Never-users & Users & Never-users \\
\hline & Obese $(\geq 30)$ & $63(29 \%)$ & $300(21 \%)$ & 74 (32\%) & 238 (19\%) \\
\hline & Missing & 125 & 917 & 138 & 784 \\
\hline \multirow[t]{4}{*}{ Selected comorbidities } & Heart failure & $51(15 \%)$ & $58(2 \%)$ & $64(17 \%)$ & $61(3 \%)$ \\
\hline & Myocardial infarction & $38(11 \%)$ & $124(5 \%)$ & $48(13 \%)$ & $115(6 \%)$ \\
\hline & Hypertension & 187 (55\%) & 979 (41\%) & 217 (58\%) & $826(41 \%)$ \\
\hline & Edema & $79(23 \%)$ & $185(8 \%)$ & $86(23 \%)$ & $148(7 \%)$ \\
\hline
\end{tabular}

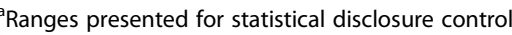

${ }^{b}$ After cancer diagnosis, using a 6 months lag (same as furosemide)

account for the dose and duration of use. In which, we categorised the patients as non-users (as described above), short-term users between 6 months after their first prescription and 6 months after their 365th DDD (or 12th prescription, approximately corresponding to 1 year of issued medication) and long-term users after that time. These analyses were repeated restricting the cohort to patients with any pre-diagnosis furosemide indications, described above, to attempt to reduce the impact of confounding by indication [25]. All of these analyses were conducted separately in esophageal and gastric cancer patients.

\section{Sensitivity and subgroup analysis}

Various sensitivity and subgroup analyses were conducted. We performed an analysis changing the outcome to cause of death from any cancer, and any cause. Subgroup analyses were conducted by the main histological subtypes (adenocarcinoma and SCC), among patients who underwent surgery within 6 months of diagnosis and by year of cancer diagnosis. We conducted an analysis additionally adjusting for variables which were incompletely recorded such as lifestyle exposure (smoking and alcohol conjunctively, and BMI independently), and tumor characteristics (stage and grade, separately). We conducted an analysis restricted to patients with any hypertensive medications use in the year prior to cancer diagnosis, where we removed those cases whose record period before diagnosis were less than 1 year. To further investigate potential confounding by hypertension (the most common furosemide indication before diagnosis) we conducted an active comparator analysis in which we compared furosemide users after diagnosis to users of other antihypertensive medications after diagnosis, based upon a time-varying covariate with a 6 month lag [22]. Also, we conducted an analysis extending the lag to 12 months, in which individuals who died within 12 months after diagnosis were excluded and follow-up started at 12 months. As pre-clinical evidence suggested furosemide would have a greater impact on more poorly differentiated tumor [12], we repeated the analysis restricted to patients diagnosed with high grade (3 or 4 ) tumors. We also repeated the analysis for all loop diuretics (furosemide, bumetanide and torasemide) as all of them have similar NKCC inhibitor properties.

Finally, to attempt to investigate the impact of furosemide on the developing tumor we conducted an analysis of furosemide use in the year before cancer diagnosis on cancer-specific mortality, in which we started to follow participants from the date of cancer diagnosis and did not exclude deaths in the first 6 months [23]. Patients with less than 1 year of records before cancer diagnosis were excluded.

\section{Results}

Overall 4799 and 4537 newly diagnosed primary esophageal and gastric cancer patients were identified in CPRD. After exclusion of patients who died within 6 months of diagnosis, there were a total of 2708 esophageal cancer cases and 2377 gastric cancer cases included in the main analyses. In these patients, the median follow-up was 1.3 years (range 0.5 to 17.2 years) for esophageal cancer and 1.5 years (range 0.5 to 17.2 years) for gastric cancer. Patient characteristics are shown in Table 1. Furosemide users were more likely to be older (mean age at diagnosis was 75 for esophageal cancer and 77 for gastric cancer), have comorbidities (particularly HF, edema, MI, and hypertension), use statins or aspirin after diagnosis, have previously smoked and be obese $\left(B M I \geq 30 \mathrm{~kg} / \mathrm{m}^{2}\right.$ ) compared to non-users. Other characteristics were generally similar in furosemide users and non-users, see Table 1.

As shown in Table 2, there was a slight increase in both esophageal and gastric cancer-specific mortality in users of furosemide compared with non-users in the primary analyses (adjusted HR in esophageal cancer $=1.28,95 \%$ CI $1.10,1.50$ and in gastric cancer $=1.27,95 \%$ CI $1.08,1.50)$. After restricting to 


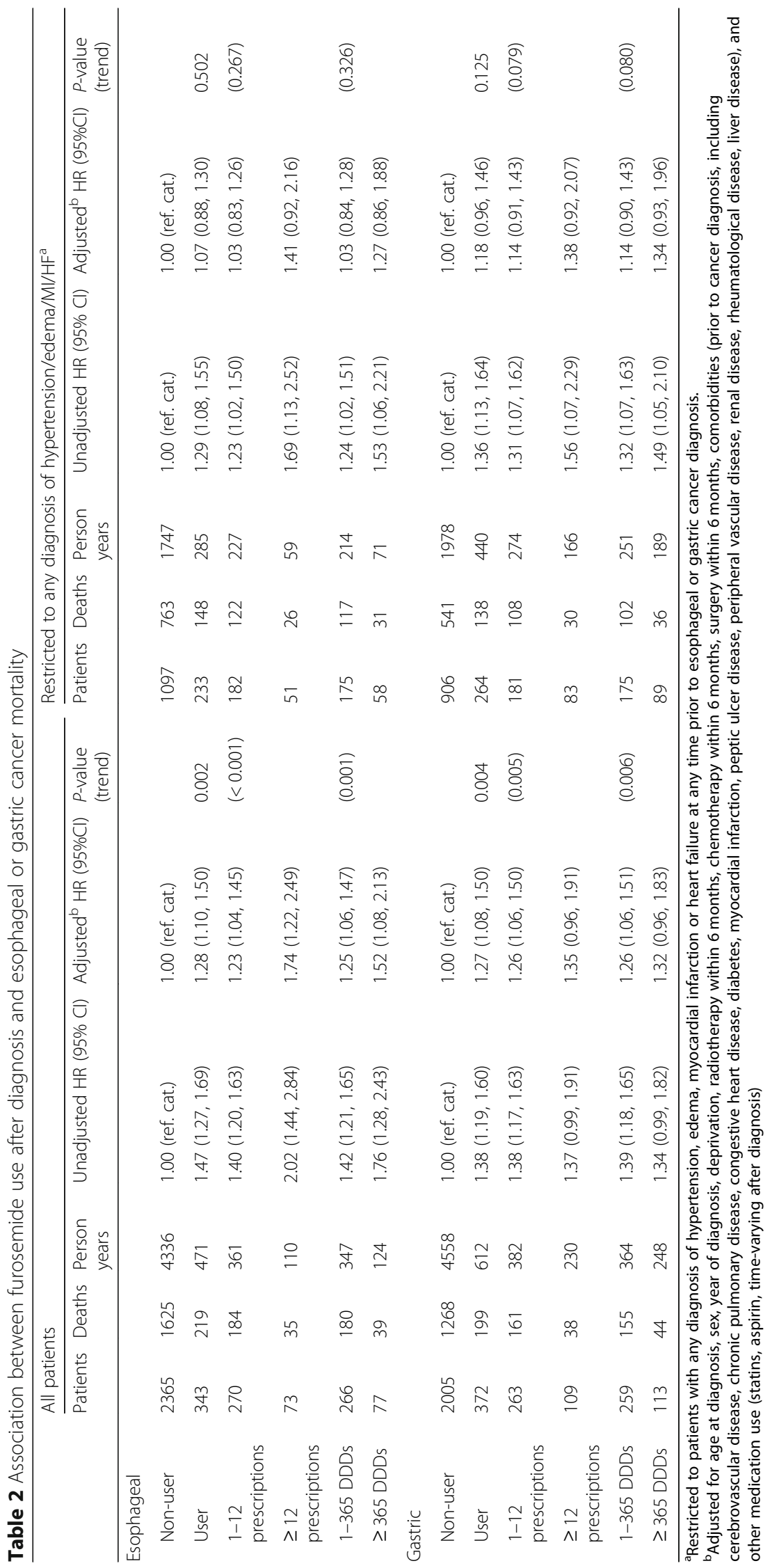


Table 3 Sensitivity and subgroup analyses for furosemide use and esophageal cancer-specific mortality

\begin{tabular}{|c|c|c|c|c|c|c|c|c|}
\hline \multirow{3}{*}{$\begin{array}{l}\text { All patients } \\
\text { b }\end{array}$} & \multicolumn{3}{|c|}{ Non-users } & \multicolumn{3}{|l|}{ Users } & \multirow{2}{*}{$\begin{array}{l}\text { Unadjusted HR } \\
(95 \% \mathrm{Cl})\end{array}$} & \multirow{2}{*}{$\begin{array}{l}\text { Adjusted }^{\mathrm{a}} \mathrm{HR} \\
(95 \% \mathrm{Cl})\end{array}$} \\
\hline & \multirow[t]{2}{*}{ Patients } & \multirow[t]{2}{*}{ Deaths } & \multirow[t]{2}{*}{$\begin{array}{l}\text { Person- } \\
\text { years }\end{array}$} & \multirow[t]{2}{*}{ Patients } & \multirow[t]{2}{*}{ Deaths } & \multirow[t]{2}{*}{$\begin{array}{l}\text { Person- } \\
\text { years }\end{array}$} & & \\
\hline & & & & & & & & \\
\hline Main analysis & 2365 & 1625 & 4336 & 343 & 219 & 471 & $\begin{array}{l}1.47(1.27 \\
1.69)\end{array}$ & $\begin{array}{l}1.28(1.10 \\
1.50)\end{array}$ \\
\hline All cancer death & 2365 & 1730 & 4336 & 343 & 248 & 471 & $\begin{array}{l}1.56(1.36 \\
1.78)\end{array}$ & $\begin{array}{l}1.34(1.16 \\
1.55)\end{array}$ \\
\hline All cause death & 2365 & 1784 & 4336 & 343 & 277 & 471 & $\begin{array}{l}1.68(1.47 \\
1.90)\end{array}$ & $\begin{array}{l}1.44(1.25 \\
1.65)\end{array}$ \\
\hline $\begin{array}{l}\text { Use in the year before } \\
\text { diagnosis }\end{array}$ & 3862 & 2836 & 5739 & 567 & 438 & 469 & $\begin{array}{l}1.46(1.32 \\
1.62)\end{array}$ & $\begin{array}{l}1.14(1.02, \\
1.28)\end{array}$ \\
\hline 12 month lag & 1481 & 883 & 3401 & 208 & 112 & 336 & $\begin{array}{l}1.56(1.28 \\
1.90)\end{array}$ & $\begin{array}{l}1.41(1.13 \\
1.75)\end{array}$ \\
\hline \multicolumn{9}{|l|}{ Tumor type ${ }^{c}$} \\
\hline Adenocarcinoma & 1478 & 1015 & 2837 & 218 & 145 & 322 & $\begin{array}{l}1.55(1.30 \\
1.85)\end{array}$ & $\begin{array}{l}1.30(1.07 \\
1.57)\end{array}$ \\
\hline Squamous cell carcinoma & 717 & 496 & 1214 & 99 & 59 & 115 & $\begin{array}{l}1.38(1.05 \\
1.81)\end{array}$ & $\begin{array}{l}1.64(1.18, \\
2.26)\end{array}$ \\
\hline $\begin{array}{l}\text { Additionally adjusted for } \\
\text { smoking and alcohol }^{d}\end{array}$ & 1391 & 1031 & 1581 & 182 & 134 & 173 & $\begin{array}{l}1.34(1.11 \\
1.60)\end{array}$ & $\begin{array}{l}1.12(0.91 \\
1.36)\end{array}$ \\
\hline Additionally adjusted for BMl ${ }^{e}$ & 1448 & 1036 & 1928 & 218 & 148 & 243 & $\begin{array}{l}1.25(1.05 \\
1.49)\end{array}$ & $\begin{array}{l}1.09(0.90 \\
1.32)\end{array}$ \\
\hline All loop diuretics ${ }^{f}$ & 2348 & 1613 & 4313 & 360 & 231 & 492 & $\begin{array}{l}1.44(1.25 \\
1.66)\end{array}$ & $\begin{array}{l}1.24(1.06 \\
1.44)\end{array}$ \\
\hline Additionally adjusted for stage ${ }^{g}$ & 473 & 285 & 641 & 47 & 26 & 62 & $\begin{array}{l}1.24(0.83 \\
1.86)\end{array}$ & $\begin{array}{l}1.19(0.74 \\
1.91)\end{array}$ \\
\hline Additionally adjusted for grade ${ }^{h}$ & 1775 & 1229 & 3131 & 246 & 164 & 312 & $\begin{array}{l}1.55(1.31 \\
1.82)\end{array}$ & $\begin{array}{l}1.44(1.20 \\
1.73)\end{array}$ \\
\hline $\begin{array}{l}\text { Restricted to patients with high } \\
\text { grade diagnosis }\end{array}$ & 908 & 661 & 1371 & 98 & 70 & 113 & $\begin{array}{l}1.55(1.21 \\
1.99)\end{array}$ & $\begin{array}{l}1.36(1.04 \\
1.79)\end{array}$ \\
\hline $\begin{array}{l}\text { Restricted to patients surgically } \\
\text { treated }\end{array}$ & 959 & 579 & 2460 & 125 & 70 & 248 & $\begin{array}{l}1.64(1.28 \\
2.11)\end{array}$ & $\begin{array}{l}1.44(1.10 \\
1.90)\end{array}$ \\
\hline $\begin{array}{l}\text { Restricted to any hypertensive } \\
\text { medication use } \mathrm{e}^{\mathrm{k}}\end{array}$ & 1062 & 736 & 1676 & 264 & 174 & 335 & $\begin{array}{l}1.34(1.13 \\
1.58)\end{array}$ & $\begin{array}{l}1.13(0.94 \\
1.36)\end{array}$ \\
\hline $\begin{array}{l}\text { Furosemide vs other antihypertensive } \\
\text { medication' }\end{array}$ & 1106 & 771 & 1909 & 343 & 219 & 471 & $\begin{array}{l}1.46(1.25 \\
1.70)\end{array}$ & $\begin{array}{l}1.27(1.07 \\
1.49)\end{array}$ \\
\hline Year of diagnosis ${ }^{m}: 1998$ to 2002 & 482 & 372 & 1095 & 85 & 58 & 131 & $\begin{array}{l}1.72(1.30 \\
2.27)\end{array}$ & $\begin{array}{l}1.46(1.06 \\
1.99)\end{array}$ \\
\hline 2003 to 2007 & 789 & 601 & 1701 & 123 & 80 & 179 & $\begin{array}{l}1.45(1.15 \\
1.84)\end{array}$ & $\begin{array}{l}1.28(0.99 \\
1.65)\end{array}$ \\
\hline 2008 to 2013 & 1094 & 652 & 1540 & 135 & 81 & 162 & $\begin{array}{l}1.32(1.05 \\
1.67)\end{array}$ & $\begin{array}{l}1.22(0.94 \\
1.59)\end{array}$ \\
\hline \multicolumn{9}{|l|}{$\begin{array}{l}\text { Restricted to any diagnosis of } \\
\text { hypertension/edema/MI/HF }\end{array}$} \\
\hline Main analysis & 1097 & 763 & 1747 & 233 & 148 & 285 & $\begin{array}{l}1.29(1.08, \\
1.55)\end{array}$ & $\begin{array}{l}1.07(0.88 \\
1.30)\end{array}$ \\
\hline 12 month lag & 683 & 422 & 1314 & 138 & 75 & 194 & $\begin{array}{l}1.31(1.02 \\
1.68)\end{array}$ & $\begin{array}{l}1.04(0.79 \\
1.37)\end{array}$ \\
\hline \multicolumn{9}{|l|}{ Tumor type ${ }^{\circ}$} \\
\hline Adenocarcinoma & 715 & 493 & 1192 & 146 & 98 & 188 & $\begin{array}{l}1.43(1.14 \\
1.78)\end{array}$ & $\begin{array}{l}1.08(0.85 \\
1.39)\end{array}$ \\
\hline Squamous cell carcinoma & 310 & 214 & 471 & 71 & 41 & 78 & $\begin{array}{l}1.18(0.85 \\
1.66)\end{array}$ & $\begin{array}{l}1.32(0.87 \\
2.00)\end{array}$ \\
\hline
\end{tabular}


Table 3 Sensitivity and subgroup analyses for furosemide use and esophageal cancer-specific mortality (Continued)

\begin{tabular}{|c|c|c|c|c|c|c|c|c|}
\hline & \multicolumn{3}{|c|}{ Non-users } & \multicolumn{3}{|l|}{ Users } & \multirow{2}{*}{$\begin{array}{l}\text { Unadjusted HR } \\
(95 \% \mathrm{Cl})\end{array}$} & \multirow{2}{*}{$\begin{array}{l}\text { Adjusted }^{a} \mathrm{HR} \\
(95 \% \mathrm{Cl})\end{array}$} \\
\hline & Patients & Deaths & $\begin{array}{l}\text { Person- } \\
\text { years }\end{array}$ & Patients & Deaths & $\begin{array}{l}\text { Person- } \\
\text { years }\end{array}$ & & \\
\hline $\begin{array}{l}\text { Additionally adjusted for smoking } \\
\text { and alcohol }\end{array}$ & 758 & 567 & 785 & 137 & 97 & 137 & $\begin{array}{l}1.15(0.92 \\
1.43)\end{array}$ & $\begin{array}{l}0.95(0.74 \\
1.21)\end{array}$ \\
\hline Additionally adjusted for BMI ${ }^{e}$ & 774 & 562 & 900 & 162 & 107 & 182 & $\begin{array}{l}1.03(0.83 \\
1.27)\end{array}$ & $\begin{array}{l}0.83(0.65 \\
1.05)\end{array}$ \\
\hline All loop diuretics ${ }^{f}$ & 1082 & 752 & 1730 & 248 & 159 & 302 & $\begin{array}{l}1.28(1.08 \\
1.52)\end{array}$ & $\begin{array}{l}1.03(0.84 \\
1.25)\end{array}$ \\
\hline Additionally adjusted for Stage ${ }^{g}$ & 275 & 160 & 351 & 33 & 17 & 32 & $\begin{array}{l}1.29(0.78 \\
2.14)\end{array}$ & $\begin{array}{l}1.37(0.76 \\
2.48)\end{array}$ \\
\hline Additionally adjusted for Grade ${ }^{h}$ & 832 & 578 & 1328 & 172 & 112 & 211 & $\begin{array}{l}1.41(1.15 \\
1.72)\end{array}$ & $\begin{array}{l}1.25(0.99 \\
1.57)\end{array}$ \\
\hline Year of diagnosisp: 1998 to 2002 & 149 & 120 & 290 & 43 & 30 & 47 & $\begin{array}{l}1.47(0.98 \\
2.20)\end{array}$ & $\begin{array}{l}1.07(0.65 \\
1.77)\end{array}$ \\
\hline 2003 to 2007 & 348 & 279 & 685 & 83 & 58 & 112 & $\begin{array}{l}1.34(1.01 \\
1.79)\end{array}$ & $\begin{array}{l}1.12(0.81 \\
1.54)\end{array}$ \\
\hline 2008 to 2013 & 600 & 364 & 772 & 107 & 60 & 126 & $\begin{array}{l}1.16(0.88 \\
1.52)\end{array}$ & $\begin{array}{l}0.99(0.72 \\
1.36)\end{array}$ \\
\hline
\end{tabular}

${ }^{a}$ Adjusted for age at diagnosis, sex, year of diagnosis, deprivation, radiotherapy within 6 months, chemotherapy within 6 months, surgery within 6 months, comorbidities (prior to diagnosis, including cerebrovascular disease, chronic pulmonary disease, congestive heart disease, diabetes, myocardial infarction, peptic ulcer disease, peripheral vascular disease, renal disease, rheumatological disease and liver disease), and other medication use (statins, aspirin, time-varying after diagnosis)

${ }^{\mathrm{b}}$ Sensitivity analyses based on the primary main analyses, including all eligible patients except were indicated

${ }^{c} P$-value for interaction for esophageal cancer is 0.794

${ }^{\mathrm{d}}$ Restricted to patient with smoking and alcohol records

eRestricted to patient with BMI records

${ }^{f}$ Association between all loop diuretics (including furosemide, bumetanide and torasemide) use after diagnosis and gastric or esophageal cancer mortality

${ }^{g}$ Additionally adjusted for tumor stage

${ }^{\mathrm{h}}$ Additionally adjusted for tumor grade

'Restricted to patients who were diagnosed as grade 3 or 4 cancer

${ }^{\mathrm{j}}$ Restricted to patients who received the surgery treatment within 6 months of diagnosis

${ }^{\mathrm{k}}$ Restricted to patients with any antihypertensive medication use in the year prior to cancer diagnosis

'Using other antihypertensive medications after cancer diagnosis as an active comparator

${ }^{m} P$-value for interaction across cancer diagnosis year is 0.265

${ }^{n}$ Restricted to patients with any diagnosis of hypertension, edema, myocardial infarction or heart failure at any time prior to esophageal cancer diagnosis

${ }^{\circ} P$-value for interaction for esophageal cancer is 0.524

${ }^{\mathrm{p}} \mathrm{P}$-value for interaction across cancer diagnosis year is 0.964

patients with identified indications for furosemide, to compare the furosemide users to more similar nonusers, there was no significant association between furosemide use and cancer-specific mortality in patients with esophageal or gastric cancer (adjusted HR in esophageal cancer $=1.07,95 \%$ CI $0.88,1.30$ and in gastric cancer $=1.18,95 \%$ CI 0.96, 1.46). Similarly, in analyses accounting for dose and duration of use in the restricted cohort, the adjusted HRs for over 1 year of furosemide use (i.e. 365 DDDS) were 1.27 (95\% CI $0.86,1.88)$ and 1.34 (95\% CI 0.93, 1.96) in esophageal and gastric cancer patients, respectively (Table 2).

Sensitivity analyses generally showed similar associations to the main results (Tables 3 and 4). In particular, associations were similar when the use of furosemide in the year before diagnosis was investigated, when a 12 month lag was used, when stratified by histological tumor subtype, when stratified by year of diagnosis, when exposure was expanded to all loop diuretics, after additional adjustment for BMI, after additional adjustment for smoking and alcohol, after additional adjustment for tumor stage or grade, and when restricted to patients diagnosed with high grade tumors. The analyses were also similar when restricting to patients who were users of any antihypertensive medications in the year prior to cancer diagnosis, and when using an active comparator to compare users of furosemide to users of other antihypertensive medications after cancer diagnosis. There was a slight increase in all-cancer and all-cause mortality in users of furosemide, compared with non-users, for both esophageal and gastric cancer patients. Furthermore, there was a slight increase in cancer-specific mortality with furosemide use when restricted to surgically treated patients (Tables 3 and 4).

\section{Discussion}

In this large population-based cohort we did not find evidence that furosemide was associated with a 
Table 4 Sensitivity and subgroup analyses for furosemide use and gastric cancer-specific mortality

\begin{tabular}{|c|c|c|c|c|c|c|c|c|}
\hline \multirow{3}{*}{ 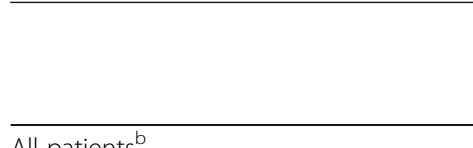 } & \multicolumn{3}{|c|}{ Non-users } & \multicolumn{3}{|l|}{ Users } & \multirow[b]{2}{*}{$\begin{array}{l}\text { Unadjusted } \\
\text { HR (95\% Cl) }\end{array}$} & \multirow[b]{2}{*}{$\begin{array}{l}\text { Adjusted }^{\mathrm{a}} \\
\text { HR }(95 \% \mathrm{Cl})\end{array}$} \\
\hline & Patients & Deaths & $\begin{array}{l}\text { Person- } \\
\text { years }\end{array}$ & Patients & Deaths & $\begin{array}{l}\text { Person- } \\
\text { years }\end{array}$ & & \\
\hline & \multicolumn{8}{|c|}{ All patients ${ }^{\mathrm{b}}$} \\
\hline Main analysis & 2005 & 1268 & 4558 & 372 & 199 & 612 & $\begin{array}{l}1.38(1.19 \\
1.60)\end{array}$ & $\begin{array}{l}1.27(1.08 \\
1.50)\end{array}$ \\
\hline All cancer death & 2005 & 1405 & 4558 & 372 & 244 & 612 & $\begin{array}{l}1.50(1.31 \\
1.72)\end{array}$ & $\begin{array}{l}1.37(1.18 \\
1.59)\end{array}$ \\
\hline All cause death & 2005 & 1512 & 4558 & 372 & 293 & 612 & $\begin{array}{l}1.63(1.44 \\
1.85)\end{array}$ & $\begin{array}{l}1.44(1.25 \\
1.65)\end{array}$ \\
\hline $\begin{array}{l}\text { Use in the year before } \\
\text { diagnosis }\end{array}$ & 3584 & 2534 & 5693 & 608 & 431 & 573 & $\begin{array}{l}1.32(1.19 \\
1.46)\end{array}$ & $\begin{array}{l}1.12(1.00 \\
1.26)\end{array}$ \\
\hline 12 month lag & 1360 & 712 & 3733 & 234 & 101 & 464 & $\begin{array}{l}1.35(1.10 \\
1.67)\end{array}$ & $\begin{array}{l}1.21(0.96 \\
1.53)\end{array}$ \\
\hline Adenocarcinoma & 1813 & 1182 & 4015 & 336 & 186 & 561 & $\begin{array}{l}1.33(1.14 \\
1.55)\end{array}$ & $\begin{array}{l}1.25(1.05 \\
1.49)\end{array}$ \\
\hline $\begin{array}{l}\text { Additional adjusted for } \\
\text { smoking and alcohol }^{c}\end{array}$ & 1091 & 780 & 1469 & 206 & 133 & 204 & $\begin{array}{l}1.30(1.08 \\
1.56)\end{array}$ & $\begin{array}{l}1.41(1.13 \\
1.75)\end{array}$ \\
\hline Additional adjusted for $B M l^{d}$ & 1221 & 825 & 1984 & 234 & 135 & 282 & $\begin{array}{l}1.27(1.06 \\
1.53)\end{array}$ & $\begin{array}{l}1.26(1.02 \\
1.54)\end{array}$ \\
\hline All loop diuretics ${ }^{e}$ & 1984 & 1256 & 4514 & 393 & 211 & 656 & $\begin{array}{l}1.35(1.17 \\
1.56)\end{array}$ & $\begin{array}{l}1.27(1.08 \\
1.50)\end{array}$ \\
\hline $\begin{array}{l}\text { Additionally adjusted for } \\
\text { Stage }^{f}\end{array}$ & 270 & 155 & 409 & 43 & 18 & 66 & $\begin{array}{l}0.88(0.54 \\
1.44)\end{array}$ & $\begin{array}{l}0.64(0.35 \\
1.15)\end{array}$ \\
\hline $\begin{array}{l}\text { Additionally adjusted for } \\
\text { Grade }^{g}\end{array}$ & 1462 & 945 & 3316 & 258 & 134 & 422 & $\begin{array}{l}1.31(1.09 \\
1.57)\end{array}$ & $\begin{array}{l}1.26(1.03 \\
1.54)\end{array}$ \\
\hline $\begin{array}{l}\text { Restricted to patients with } \\
\text { high grade diagnosish }\end{array}$ & 909 & 610 & 1770 & 137 & 81 & 207 & $\begin{array}{l}1.34(1.06 \\
1.69)\end{array}$ & $\begin{array}{l}1.37(1.05 \\
1.79)\end{array}$ \\
\hline $\begin{array}{l}\text { Restricted to patients surgically } \\
\text { treated }^{i}\end{array}$ & 1029 & 556 & 3198 & 181 & 85 & 385 & $\begin{array}{l}1.64(1.30 \\
2.06)\end{array}$ & $\begin{array}{l}1.74(1.35 \\
2.23)\end{array}$ \\
\hline $\begin{array}{l}\text { Restricted to any hypertensive } \\
\text { medication use }\end{array}$ & 899 & 563 & 1914 & 283 & 149 & 434 & $\begin{array}{l}1.31(1.09 \\
1.57)\end{array}$ & $\begin{array}{l}1.14(0.93 \\
1.39)\end{array}$ \\
\hline $\begin{array}{l}\text { Furosemide vs other antihypertensive } \\
\text { medication }^{k}\end{array}$ & 953 & 593 & 2169 & 372 & 199 & 612 & $\begin{array}{l}1.49(1.27 \\
1.76)\end{array}$ & $\begin{array}{l}1.31(1.10 \\
1.57)\end{array}$ \\
\hline Year of diagnosis: 1998 to 2002 & 507 & 365 & 1496 & 116 & 67 & 232 & $\begin{array}{l}1.52(1.17 \\
1.98)\end{array}$ & $\begin{array}{l}1.50(1.11 \\
2.02)\end{array}$ \\
\hline 2003 to 2007 & 719 & 476 & 1779 & 126 & 76 & 211 & $\begin{array}{l}1.60(1.25 \\
2.04)\end{array}$ & $\begin{array}{l}1.64(1.24 \\
2.15)\end{array}$ \\
\hline 2008 to 2013 & 779 & 427 & 1283 & 130 & 56 & 169 & $\begin{array}{l}1.07(0.81 \\
1.41)\end{array}$ & $\begin{array}{l}1.01(0.74 \\
1.38)\end{array}$ \\
\hline \multicolumn{9}{|l|}{$\begin{array}{l}\text { Restricted to any diagnosis of } \\
\text { hypertension/edema/MI/HF }\end{array}$} \\
\hline Main analysis & 906 & 541 & 1978 & 264 & 138 & 440 & $\begin{array}{l}1.36(1.13 \\
1.64)\end{array}$ & $\begin{array}{l}1.18(0.96 \\
1.46)\end{array}$ \\
\hline 12 month lag & 615 & 288 & 1606 & 168 & 75 & 334 & $\begin{array}{l}1.46(1.13 \\
1.88)\end{array}$ & $\begin{array}{l}1.22(0.91 \\
1.64)\end{array}$ \\
\hline Adenocarcinoma & 813 & 502 & 1721 & 235 & 130 & 393 & $\begin{array}{l}1.33(1.10 \\
1.62)\end{array}$ & $\begin{array}{l}1.16(0.93 \\
1.44)\end{array}$ \\
\hline 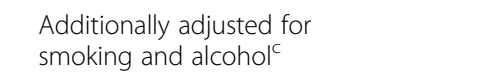 & 550 & 368 & 739 & 160 & 101 & 155 & $\begin{array}{l}1.36(1.09, \\
1.70)\end{array}$ & $\begin{array}{l}1.36(1.04 \\
1.77)\end{array}$ \\
\hline Additionally adjusted for BMI ${ }^{d}$ & 630 & 401 & 1013 & 177 & 99 & 223 & $\begin{array}{l}1.24(0.99 \\
1.55)\end{array}$ & $\begin{array}{l}1.14(0.89 \\
1.47)\end{array}$ \\
\hline All loop diuretics ${ }^{\mathrm{e}}$ & 890 & 533 & 1949 & 280 & 146 & 470 & $\begin{array}{l}1.34(1.11 \\
1.61)\end{array}$ & $\begin{array}{l}1.18(0.96 \\
1.45)\end{array}$ \\
\hline
\end{tabular}


Table 4 Sensitivity and subgroup analyses for furosemide use and gastric cancer-specific mortality (Continued)

\begin{tabular}{|c|c|c|c|c|c|c|c|c|}
\hline & \multicolumn{3}{|c|}{ Non-users } & \multicolumn{3}{|l|}{ Users } & \multirow[b]{2}{*}{$\begin{array}{l}\text { Unadjusted } \\
\text { HR }(95 \% \mathrm{Cl})\end{array}$} & \multirow[b]{2}{*}{$\begin{array}{l}\text { Adjusted }^{\mathrm{a}} \\
\text { HR (95\% Cl) }\end{array}$} \\
\hline & Patients & Deaths & $\begin{array}{l}\text { Person- } \\
\text { years }\end{array}$ & Patients & Deaths & $\begin{array}{l}\text { Person- } \\
\text { years }\end{array}$ & & \\
\hline Additionally adjusted for Stage ${ }^{f}$ & 129 & 68 & 154 & 33 & 51 & 46 & $\begin{array}{l}1.01(0.58, \\
1.78)\end{array}$ & $\begin{array}{l}0.53(0.24 \\
1.15)\end{array}$ \\
\hline Additionally adjusted for Grade ${ }^{g}$ & 659 & 408 & 1435 & 174 & 89 & 274 & $\begin{array}{l}1.31(1.04 \\
1.65)\end{array}$ & $\begin{array}{l}1.11(0.85 \\
1.45)\end{array}$ \\
\hline Year of diagnosis": 1998 to 2002 & 148 & 108 & 447 & 69 & 35 & 160 & $\begin{array}{l}1.24(0.85 \\
1.83)\end{array}$ & $\begin{array}{l}0.95(0.59 \\
1.54)\end{array}$ \\
\hline 2003 to 2007 & 325 & 208 & 809 & 86 & 56 & 141 & $\begin{array}{l}1.65(1.22, \\
2.22)\end{array}$ & $\begin{array}{l}1.57(1.11 \\
2.23)\end{array}$ \\
\hline 2008 to 2013 & 433 & 225 & 722 & 109 & 47 & 140 & $\begin{array}{l}1.17(0.85 \\
1.60)\end{array}$ & $\begin{array}{l}1.04(0.72 \\
1.49)\end{array}$ \\
\hline
\end{tabular}

${ }^{a}$ Adjusted for age at diagnosis, sex, year of diagnosis, deprivation, radiotherapy within 6 months, chemotherapy within 6 months, surgery within 6 months, comorbidities (prior to diagnosis, including cerebrovascular disease, chronic pulmonary disease, congestive heart disease, diabetes, myocardial infarction, peptic ulcer disease, peripheral vascular disease, renal disease, rheumatological disease and liver disease), and other medication use (statins, aspirin, time-varying after diagnosis)

${ }^{b}$ Sensitivity analyses based on the primary main analyses, including all eligible patients except were indicated

${ }^{\mathrm{c}}$ Restricted to patient with smoking and alcohol records

${ }^{\mathrm{d}}$ Restricted to patient with BMI records

${ }^{\text {e} A s s o c i a t i o n ~ b e t w e e n ~ a l l ~ l o o p ~ d i u r e t i c s ~(i n c l u d i n g ~ f u r o s e m i d e, ~ b u m e t a n i d e ~ a n d ~ t o r a s e m i d e) ~ u s e ~ a f t e r ~ d i a g n o s i s ~ a n d ~ g a s t r i c ~ c a n c e r ~ m o r t a l i t y ~}$

${ }^{f}$ Additionally adjusted for tumor stage

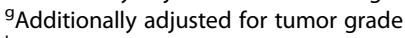

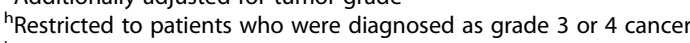

'Restricted to patients who received the surgery treatment within 6 months of diagnosis

${ }^{j}$ Restricted to patients with any antihypertensive medication use in the year prior to cancer diagnosis

${ }^{k}$ Using other antihypertensive medications after cancer diagnosis as an active comparator

' $P$-value for interaction across cancer diagnosis year is 0.390

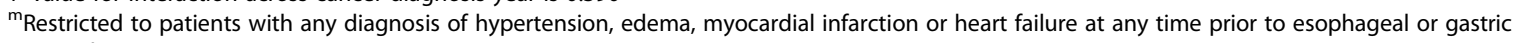
cancer diagnosis

${ }^{\mathrm{n}} P$-value for interaction across cancer diagnosis year is 0.070

reduced risk of cancer-specific or all-cause mortality in patients with esophageal or gastric cancer. In the primary analyses, we found furosemide use was associated with slightly increased mortality in patients with esophageal or gastric cancer. However, when we restricted the analyses to patients with furosemide indications, there was little evidence of any strong association between furosemide use and deaths from esophageal or gastric cancer. Findings were similar across most subgroup and sensitivity analyses.

This is, to date, the first observational study assessing the influence of furosemide use on esophageal/gastric cancer mortality. A limited number of studies have investigated furosemide use and cancer risk or survival, concentrated on investigations into breast, skin and lip cancer but not esophageal/gastric cancer, and furosemide was not the primary exposure of interest [26-28]. No consistent associations were observed for furosemide use and risk or survival of these cancers from human studies. Preclinical studies have recently shown that inhibition of the NKCC1 could slow cancer cell deterioration by influencing cancer cell growth and metastasis [11], and furosemide could reduce cell growth in poorly differentiated gastric adenocarcinoma cells [12]. In contrast, our study did not detect any evidence that users of furosemide either before or after diagnosis of esophageal or gastric cancer had reduced cancer-specific mortality. This lack of protective effect could reflect differences in drug dose, duration of use or the recognised difficulty of in vitro models to recreate the complexity of human carcinogenesis, physiology and progression [29].

The main strength of this study is that it utilised high quality data sources including cancer-registry records, ONS mortality data, and the CPRD for prescription data. In the UK, furosemide is only available through GP prescriptions and therefore these records are likely to capture all of the use in these populations [30]. The use of an electronic record of GP prescriptions also eliminated recall bias. In this study, we also had long-term follow-up, which makes it possible to assess the impact of furosemide on gastric or esophageal cancer prognosis long after diagnosis.

Confounding by indication is often encountered in pharmacoepidemiology studies as allocation of prescription is not randomized and the drug indication may be related to the outcomes of interest $[25,31]$. We conducted a number of analyses to account for confounding by indication. Firstly, we conducted analyses restricted to patients with furosemide indications, restricted to patients with any antihypertensive medications use and an active comparator analysis 


\section{Appendix}

Table $\mathbf{5}$ Edema code list

\begin{tabular}{|c|c|c|}
\hline Medcode & Readcode & Readterm \\
\hline 11,396 & R023400 & [D] Peripheral oedema \\
\hline 3158 & 183.00 & Oedema \\
\hline 6047 & $183 . .11$ & Oedema - symptom \\
\hline 1906 & $22 C 2.11$ & O/E - ankle oedema \\
\hline 4950 & R023.00 & [D] Oedema \\
\hline 6585 & $22 C 4.11$ & O/E - leg oedema \\
\hline 15,477 & $\mathrm{R} 023 z 11$ & [D] Dependent oedema \\
\hline 14,702 & R023z00 & [D] Oedema NOS \\
\hline 20,553 & $22 C 2.00$ & O/E - oedema of ankles \\
\hline 10,931 & $22 C . .00$ & O/E - oedema \\
\hline 19,358 & $22 C 4.00$ & O/E - oedema of legs \\
\hline 2140 & $183 . .12$ & Swelling - oedema - symptom \\
\hline 7321 & H541z00 & Pulmonary oedema NOS \\
\hline 1284 & $22 C 3.00$ & O/E - oedema of feet \\
\hline 30,309 & 183Z.00 & Oedema NOS \\
\hline 9108 & 1837 & Pitting oedema \\
\hline 558 & H584.00 & Acute pulmonary oedema unspecified \\
\hline 5155 & 23E1.00 & O/E - pulmonary oedema \\
\hline 7106 & $22 C 3.11$ & O/E - foot oedema \\
\hline 6651 & $22 C . .11$ & O/E - swelling - oedema \\
\hline 28,419 & $22 C Z .00$ & O/E - oedema NOS \\
\hline 5293 & $\mathrm{H} 584 \mathrm{zO0}$ & Acute pulmonary oedema NOS \\
\hline 22,500 & $8 \mathrm{E} 95.00$ & Reduction of oedema \\
\hline 20,301 & R023000 & [D] Oedema, generalized \\
\hline 43,618 & G581.12 & Pulmonary oedema - acute \\
\hline 102,627 & 183B.00 & Worsening pulmonary oedema \\
\hline 22,734 & 1838 & Sacral oedema \\
\hline 19,714 & $22 C 5.11$ & O/E - thigh oedema \\
\hline 9392 & $22 C 7.00$ & O/E - sacral oedema \\
\hline 31,747 & $22 C 6.00$ & O/E - abdominal oedema \\
\hline 61,224 & $22 C 5.00$ & $\mathrm{O} / \mathrm{E}$ - oedema of thighs \\
\hline 26,082 & H541000 & Chronic pulmonary oedema \\
\hline 108,888 & C366200 & Idiopathic oedema \\
\hline 48,466 & H584.11 & Acute oedema of lung, unspecified \\
\hline
\end{tabular}

comparing furosemide users to users of other antihypertensive drugs. In all of these analyses, no association between furosemide use and cancer-specific mortality was found. Although diuretics are sometimes used for malignant ascites, this is not likely to impact our results because furosemide is not commonly used for this purpose [32, 33]. Furthermore, application of the lag period removed prescriptions in the 6 months before death in the main analysis (and 12 months in sensitivity analysis), which would almost entirely remove use for ascites as survival with malignant ascites is very short [34]. Moreover, this potential weakness would not have impacted the analysis of furosemide use in the year before diagnosis, which also did not show evidence of improved survival with furosemide use.

Another potential weakness is that although we were able to adjust for a wide range of confounders there is the possibility of residual confounding by incompletely recorded variables such as cancer stage and lifestyle exposures. However, based on the available data, additional adjustment of some lifestyle exposures for which we had incomplete records did not change the main findings. Also, there was no difference when analysis was restricted to poorly differentiated cancers.

\section{Conclusion}

In conclusion, in the first study to investigate furosemide use and survival in esophageal and gastric cancer patients, we did not find evidence that furosemide use was associated with improved survival. Further preclinical or observational studies should be designed to investigate this association according to stratified analyses by tumor stage or molecular characteristics to fully exclude a potential role for this medication as an adjuvant therapy.

\begin{abstract}
Abbreviations
BMI: Body mass index; Cls: Confidence intervals; CPRD: Clinical Practice Research Datalink; DDD: Defined Daily Doses; GP: General practitioner; HF: Heart failure; HR: Hazard ratio; ICD: International Classification of Diseases; ICD-O: ICD for Oncology; MI: Myocardial infarction; NCDR: National Cancer Data Repository; NKCC: Na-K-2CI (NKCC) transporter; ONS: Office of National Statistics; UK: United Kingdom
\end{abstract}

\section{Acknowledgements}

None.

Authors' contributions

Study design (CC, PL, AS), statistical analyses (PL, ÚM, CC), interpretation of data $(P L, U ́ M, A S, B J, H C, C C)$, drafting the manuscript $(P L, C C)$, all authors have read and approved the final manuscript (PL, ÚM, AS, BJ, HC, CC).

\section{Funding}

This work was supported by a Clinical Research Bursary from Cancer Research-UK (C54914/A20558). Peipei Liu was supported by a joint scholarship from Queen's University of Belfast and the Chinese Scholarship Council (CSC201708060458). The funding bodies have no role in study design, collection, analysis, interpretation of data or writing the manuscript.

\section{Availability of data and materials}

The data that support the findings of this study are available from CPRD database but restrictions apply to the availability of these data, which were used under license for the current study, and so are not publicly available. STATA code used to conduct analysis is available from the corresponding author on reasonable request.

\section{Ethics approval and consent to participate}

The study protocol was approved by the Independent Scientific Advisory Committee for Medicines and Healthcare products Regulatory Agency Database Research (protocol number: 15 096RMn3). This study is based in part on data from the CPRD obtained under licence from the UK Medicines 
and Healthcare Products Regulatory Agency. The CPRD collects de-identified data from a network of GP practices therefore no written informed consent was obtained. The interpretation and conclusions contained in this study are those of the authors alone.

\section{Consent for publication}

Not applicable.

\section{Competing interests}

The authors declare that they have no competing of interests.

\section{Author details}

${ }^{1}$ Centre for Public Health, Queen's University Belfast, Institute for Clinical Science, Royal Victoria Hospital, Grosvenor Road, Belfast, Belfast, Northern Ireland BT12 6BJ, UK. 'elfast Health and Social Care Trust, Belfast, Northern Ireland, UK. ${ }^{3}$ Centre for Cancer Research and Cell Biology, Queen's University Belfast, Belfast, Northern Ireland, UK.

Received: 27 February 2019 Accepted: 3 October 2019

Published online: 29 October 2019

\section{References}

1. Bray F, Ferlay J, Soerjomataram I, et al. Global cancer statistics 2018: GLOBOCAN estimates of incidence and mortality worldwide for 36 cancers in 185 countries. CA Cancer J Clin. 2018;68(6):394-424.

2. Office for National Statistics. Cancer Survival in England: Patients Diagnosed between 2011 and 2015 and Followed up to 2016. 2016. https://www.ons. gov.uk/peoplepopulationandcommunity/healthandsocialcare/ conditionsanddiseases/bulletins/cancersurvivalinengland/ adultstageatdiagnosisandchildhoodpatientsfollowedupto2016.

3. Cotter G, Metzkor E, Kaluski E F, et al. Randomised trial of high-dose isosorbide dinitrate plus low-dose furosemide versus high-dose furosemide plus low-dose isosorbide dinitrate in severe pulmonary oedema. Lancet. 1998;351(9100):389-93.

4. Michael FG. Diuretic Management in Heart Failure. Congest Hear Fail. 2010; 16:S68-72.

5. Weber MA, Schiffrin EL, White WB, et al. Clinical practice guidelines for the Management of Hypertension in the community. J Clin Hypertens. 2014; 16(1):14-26.

6. Elwell RJ, Spencer AP, Eisele G. Combined furosemide and human albumin treatment for diuretic-resistant edema. Ann Pharmacother. 2003;37(5):695-700.

7. Shankar SS, Brater DC. Loop diuretics: from the Na-K-2Cl transporter to clinical use. Am J Physiol Physiol. 2003;284(1):F11-21.

8. Oberleithner $\mathrm{H}$, Giebisch $\mathrm{G}$, Lang F, et al. Cellular mechanism of the furosemide sensitive transport system in the kidney. Klin Wochenschr. 1982; 60(19):1173-9.

9. Orlov SN, Koltsova SV, Kapilevich LV, et al. NKCC1 and NKCC2: the pathogenetic role of cation-chloride cotransporters in hypertension. Genes Dis. 2015;2(2):186-96.

10. Panet R, Marcus M, Atlan $\mathrm{H}$. Overexpression of the $\mathrm{Na}+/ \mathrm{K}+/ \mathrm{cl}$ ? Cotransporter gene induces cell proliferation and phenotypic transformation in mouse fibroblasts. J Cell Physiol. 2000;182(1):109-18.

11. Iwamoto LM, Fujiwara N, Nakamura KT, et al. Na-K-2Cl cotransporter inhibition impairs human lung cellular proliferation. Am J Physiol Cell Mol Physiol. 2004;287(3):L510-4

12. Shiozaki A, Miyazaki $\mathrm{H}$, Niisato $\mathrm{N}$, et al. Furosemide, a blocker of $\mathrm{Na}+$ $\mathrm{K}+/ 2 \mathrm{Cl}-$ Cotransporter, diminishes proliferation of poorly differentiated human gastric Cancer cells by affecting G0/G1 state. J Physiol Sci. 2006; 56(6):401-6.

13. Shiozaki A, Nako $Y$, Ichikawa $D$, et al. Role of the $\mathrm{Na}^{+} / \mathrm{K}^{+} / 2 \mathrm{Cl}^{-}$cotransporter NKCC1 in cell cycle progression in human esophageal squamous cell carcinoma. World J Gastroenterol. 2014;20(22):6844-59.

14. Herrett E, Gallagher AM, Bhaskaran K, et al. Data resource profile: clinical practice research Datalink (CPRD). Int J Epidemiol. 2015;44(3):827-36.

15. Khan NF, Perera R, Harper $S$, et al. Adaptation and validation of the Charlson index for read/OXMIS coded databases. BMC Fam Pract. 2010;11(1):1.

16. Nahler G. Defined daily dose (DDD). In: Dictionary of Pharmaceutical Medicine. Vienna: Springer Vienna; 2009. p. 49.

17. DCLG. The English Indices of Deprivation 2010 - Technical Report:; 2010. www. communities.gov.ukcommunity, opportunity, prosperity. Accessed 15 Oct 2018.
18. Conrad N, Judge A, Tran J, et al. Temporal trends and patterns in heart failure incidence: a population-based study of 4 million individuals. Lancet. 2018;391:572-80.

19. Cassell A, Edwards D, Harshfield A, et al. The epidemiology of multimorbidity in primary care: a retrospective cohort study. Br J Gen Pract. 2018;68(669):e245-51.

20. Nielsen SF, Nordestgaard BG, Bojesen SE. Statin use and reduced Cancerrelated mortality. N Engl J Med. 2012;367(19):1792-802.

21. Elwood PC, Morgan G, Pickering JE, et al. Aspirin in the treatment of cancer: reductions in metastatic spread and in mortality: a systematic review and meta-analyses of published studies. Ali R, ed. PLoS One. 2016;11(4):e0152402.

22. Lund $J$, Richardson DB, Stürmer T. The active comparator, new user study design in pharmacoepidemiology: historical foundations and contemporary application. Curr Epidemiol reports. 2015;2(4):221-8.

23. Lévesque LE, Hanley JA, Kezouh A, et al. Problem of immortal time bias in cohort studies: example using statins for preventing progression of diabetes. BMJ. 2010;340:b5087.

24. Chubak J, Boudreau DM, Wirtz HS, et al. Threats to validity of nonrandomized studies of Postdiagnosis exposures on Cancer recurrence and survival. JNCI J Natl Cancer Inst. 2013;105(19):1456-62.

25. Salas M, Hotman A, Stricker BH. Confounding by indication: an example of variation in the use of epidemiologic terminology. Am J Epidemiol. 1999:149(11):981-3.

26. Chen L, Chubak J, Boudreau DM, et al. Use of antihypertensive medications and risk of adverse breast Cancer outcomes in a SEER-Medicare population. Cancer Epidemiol Biomark Prev. 2017;26(11):1603-10.

27. Jensen $A \varnothing$, Thomsen HF, Engebjerg MC, et al. Use of photosensitising diuretics and risk of skin cancer: a population-based case-control study. $\mathrm{Br}$ J Cancer. 2008;99(9):1522.

28. Pottegård $A$, Hallas J, Olesen $M$, et al. Hydrochlorothiazide use is strongly associated with risk of lip cancer. J Intern Med. 2017;282(4):322-31.

29. Mak IW, Evaniew N, Ghert M. Lost in translation: animal models and clinical trials in cancer treatment. Am J Transl Res. 2014;6(2):114-8

30. García Rodríguez LA, Pérez GS. Use of the UK general practice research database for pharmacoepidemiology. Br J Clin Pharmacol. 2002;45(5):419-25.

31. Signorello LB, McLaughlin JK, Lipworth $L$, et al. Confounding by indication in epidemiologic studies of commonly used analgesics. Am J Ther. 2002;9(3):199-205.

32. Lee CW, Bociek G, Faught W. A survey of practice in management of malignant ascites. J Pain Symptom Manag. 1998;16(2):96-101.

33. Zink J, Greenway CV. Control of ascites absorption in anesthetized cats: effects of intraperitoneal pressure, protein, and furosemide diuresis. Gastroenterology. 1977;73(5):1119-24.

34. Adam RA, Adam YG. Malignant ascites: past, present, and future. J Am Coll Surg. 2004;198(6):999-1011.

\section{Publisher's Note}

Springer Nature remains neutral with regard to jurisdictional claims in published maps and institutional affiliations.

Ready to submit your research? Choose BMC and benefit from:

- fast, convenient online submission

- thorough peer review by experienced researchers in your field

- rapid publication on acceptance

- support for research data, including large and complex data types

- gold Open Access which fosters wider collaboration and increased citations

- maximum visibility for your research: over $100 \mathrm{M}$ website views per year

At $\mathrm{BMC}$, research is always in progress.

Learn more biomedcentral.com/submissions 